Investigations

\title{
Clostridia in Commercial Fish of the Azov and Black Seas and in Aquaculture Facilities in the Southern Region of Russia
}

\author{
${ }^{1}$ Yuriy Aleksandrovich Fedorov, ${ }^{2}$ Marina Aleksandrovna Morozova and ${ }^{1}$ Roman Gennad'yevich Trubnik \\ ${ }^{1}$ Southern Federal University, 344006, 105/42 st. Bol'shaya Sadovaya, Rostov-on-Don, Russia \\ ${ }^{2}$ Azov Fisheries Research Institute, 344002, 21 st. Beregovaya, Rostov-on-Don, Russia
}

\author{
Article history \\ Received: 06-11-2018 \\ Revised: 17-01-2019 \\ Accepted: 31-01-2019 \\ Corresponding Author: \\ Roman Gennad'yevich Trubnik \\ Southern Federal University, \\ 344006, 105/42 st. Bol'shaya \\ Sadovaya, Rostov-on-Don, \\ Russia \\ E-mail: trubnikroman@outlook.com
}

\begin{abstract}
The paper presents studies on the infection with clostridia of fish with skin lesions and ulcers on the surface of the body. The objects of study were syrman goby from the eastern part of the Taganrog Bay of the Sea of Azov, turbot from the shelf zone of the north-eastern Black Sea and carps reared under aquaculture conditions. Using an Autoflex speed III Bruker Daltonics (Germany) mass spectrometer, by the MALDI-TOF mass spectrometry was showed that sulfite-reducing clostridia (Clostridium perfringens, $C$. sporogenes) have been shown to infect the organs and tissues of syrman goby with vibriosis and turbot with ulcerative skin lesions of unknown etiology. Species such as Clostridium difficile, Clostridium novyi are of clinical importance and were found in the parenchymal organs of carp suffering from chronic aeromonas infection on pond fish farms in the southern Russia. These bacteria are its cosmopolitan distribution ability them to generate heat-resistant spores and cause food poisoning, which makes control and prevention measures needed in the food chain.
\end{abstract}

Keywords: Clostridia, Commercial Fish, Disease, Spores, The Azov Sea, The Black Sea, Turbot

\section{Introduction}

Clostridium (lat. Clostridium) are gram-positive spore-forming anaerobic bacteria. Today, bacteria of the Clostridium genus are a large and widespread group among anaerobes. They are found in various climatic zones, in a wide variety of soils, in water and bottom sediments of lakes, rivers, seas and oceans (La Sala et al., 2015; Abia et al., 2015; Trubnik et al., 2017; Fedorov et al., 2018). The formation of spores provides them with the possibility of long-term conservation in the habitat until the onset of favorable conditions for vegetation (Bukharin and Litvin, 1997; El-Shorbagy et al., 2012).

According to the Bergey's Manual of Systematic Bacteriology (Holt, 1994), this genus inludes more than 100 species, now there are about 150 ones (CortésSánchez, 2018). At the same time, species of clostridia are heterogeneous both phylogenetically and phenotypically. We know the following pathogenic species: C. botulinum (botulism pathogen), C. tetani (tetanus pathogen), $C$. septicum, C. perfringens type A, C. oedematiens, C. novyi (gas gangrene pathogens), $C$. difficile, $C$. perfringens type A (pseudomembranous colitis), $C$. difficile (antibioticassociated diarrhea), C. perfringens type A (necrotic enteritis, foodborne toxicoinfection).
In the Russian Federation, a quantitative account of Sulphite-Reducing Clostridia (SRC) is provided for studies of soil, therapeutic mud, drinking water, sources of centralized drinking water supply (SanPiN 2.1.4.1074-01, 2001; Labinskaya and Volina, 2008). This group of clostridia has the property of reducing sulfites to sulfides, which is used in their identification. Since only spore anaerobes of intestinal origin could reduce sulfites, this allowed us to distinguish this group of microorganisms as sanitary and indicative. The detection of SRC indicates a once fecal contamination, as the spores allow them to persist in the environment for a long time; they grow in soil rich in humus (Labinskaya and Volina, 2008). Since SRC under favorable conditions can multiply in the environment (especially in the soil), their value as an indicator of fecal contamination is low. However, the high resistance of the spores to aggressive environmental influences and to disinfection and sterilization, makes spores an important technological indicator, allowing one to evaluate the quality of water disinfection (Tymchuk et al., 2013). Speaking of fish raw materials and fish products, in accordance with the current regulatory documents of the Russian Federation (SanPiN 2.3.2.1078-01, 2001), monitoring for the presence of sulfite-reducing clostridia in 
salted, pickled fish, preserved food, vacuum-packed products, fish fillets and minced products is provided.

The dominant representative of SRC is Clostridium perfringens (Fig. 1). This microorganism is a cosmopolitan distributed in various environments, such as soil, aquatic ecosystems, the gastrointestinal tract of animals and fish, it is found in food products as well (Santos and Norma, 2011; Guran et al., 2014; Sheyin and Solomon, 2017). The widespread distribution of this microorganism and its spores is a frequent problem for the food industry and enterprises that produce large quantities of food (Cortés-Sánchez, 2018).

It is known that $C$. perfringens is also the causative agent of wound infections, causing disease in case it penetrates wounds. There is information about the infection of hydrobionts. In dolphins and other cetaceans, it causes emphysematous myositis (gas gangrene) (Cord, 1982; Dunn, 1990; Moeller, 1989). Infection can penetrate in the injection site (Moeller, 1989). Buck et al. (1987) described the case of the death of an Atlantic bottlenose dolphin female due to clostridial myositis, which developed after the bites of a male dolphin. In the Sevastopol aquarium there were several cases of acute anaerobic infection in dolphins caused by $C$. perfringens (Greenwood, Taylor, 1978). These microorganisms are usually opportunistic pathogens and acting in combination with parasites, traumatic injuries and other factors (Andreeva, 2012). The possibility of lifetime infection of fish with clostridia is not excluded (Morozova and Fedorov, 2015; Morozova, 2017).

The aim of the study was to identify clostridia in the organs and tissues of commercial fish and aquaculture species, both in specimens clinically healthy and with damaged skin and ulcers. Detection of spores of sulfite-reducing clostridia in water where fish had been caught was also our goal.

\section{Materials and Methods}

The fish under study were commercial species: syrman goby from the eastern part of the Taganrog Bay of the Azov Sea and turbot of the Black Sea shelf (Fig. 1 and 2).

Fish sampling for analysis was carried out in 20092014. Simultaneously, microbiological analysis was done of water samples to determine the content of sulfitereducing clostridia spores in the same sites (Fig. 3).

The objects of study are selected commercial fish: syrman goby from the eastern part of Taganrog Bay of the Azov Sea and the Black Sea turbot in the Black Sea shelf (Fig. 1 and 2). Catch of fish for analysis was carried out in the period 2009-2014. In addition, microbiological analysis of water samples for the content of sulphitereducing clostridia in fish catch sites was done.

Microbiological studies of commercial carps were carried out in two fish farms of the Southern region from 2016 to 2018. Clinical examination, autopsy, microbiological analysis was performed according to standard methods (Kanaev, 1973; Labinskaya and Volina, 2008; Instruction book instructions..., 1998). The biomaterial for the study was collected from living fish at least 10-15 specimens from each studied species. In commercial fish from the Azov and Black Seas, microbiological analysis of liver samples, a section of the intestine with the contents of the gills, muscle tissue and blood were performed. Microbiological cultures were performed from 600 specimens of commercial fish (clinically healthy and with ulcerative skin lesions) and from 43 water samples.

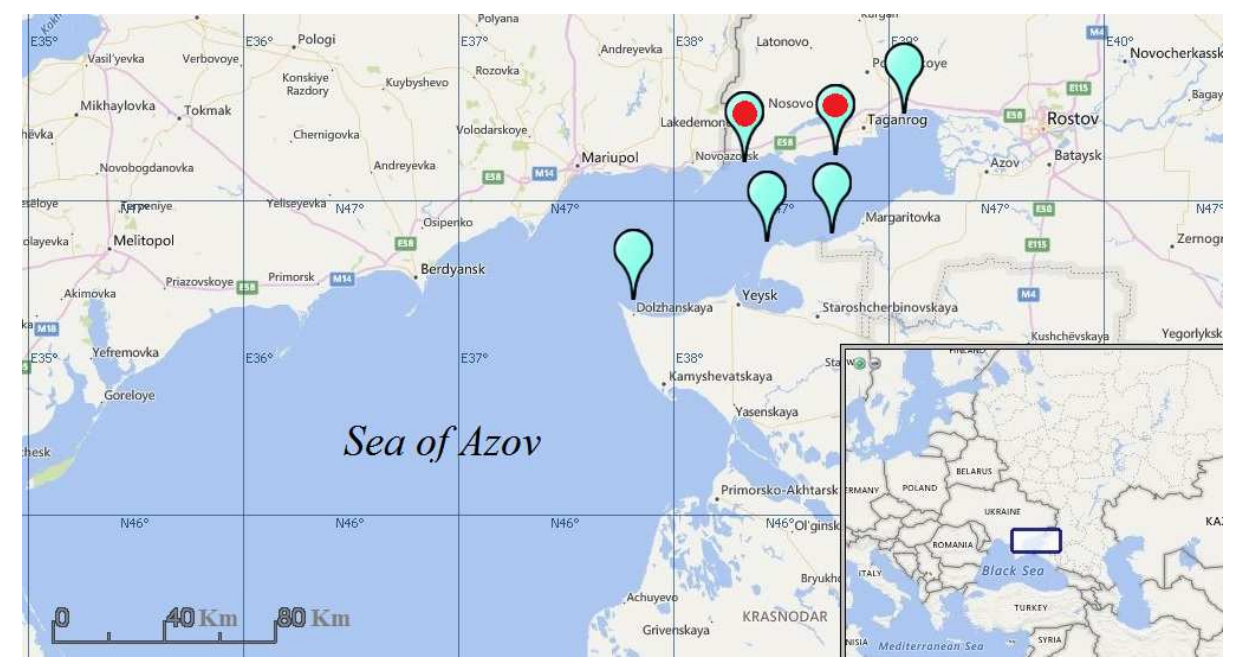

Fig. 1: Scheme of water and fish sampling stations in the north-eastern part of the Taganrog Bay of the Azov Sea; Note: sampling stations marked in red are locations where syrman goby with vibriosis were found 


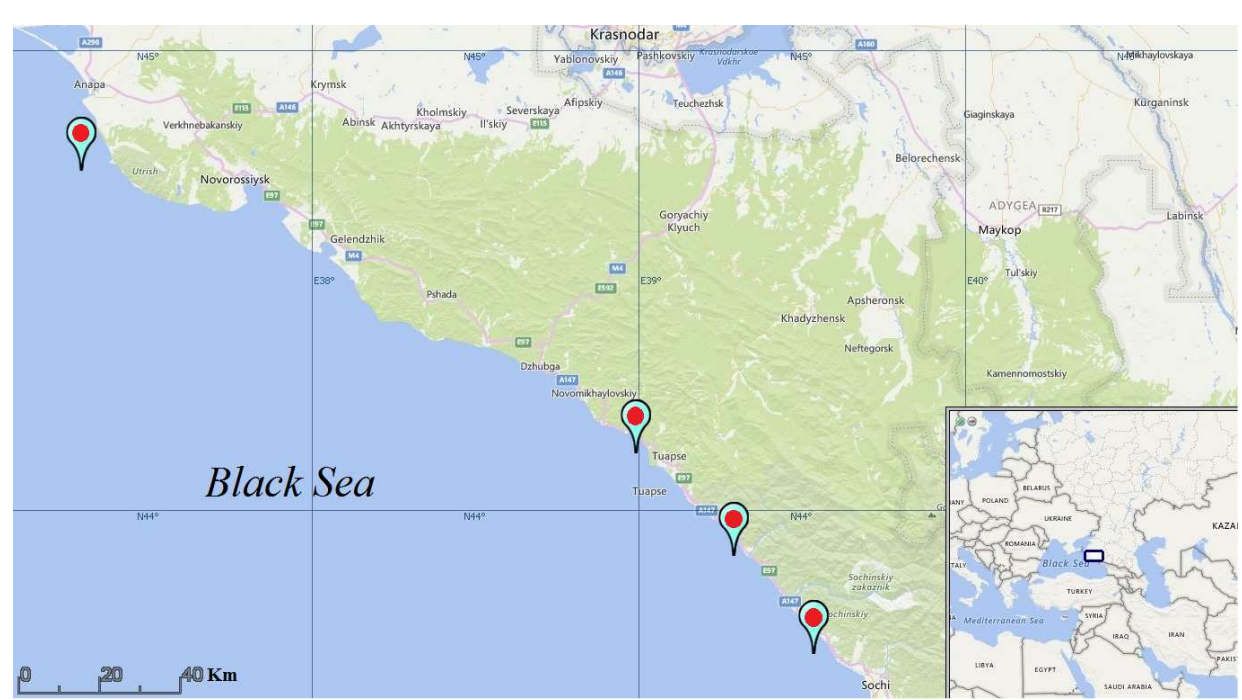

Fig. 2: Scheme of stations for sampling water and fish on the shelf of the north-eastern Black Sea; Note: Sampling stations marked with red are the places with external turbot pathology

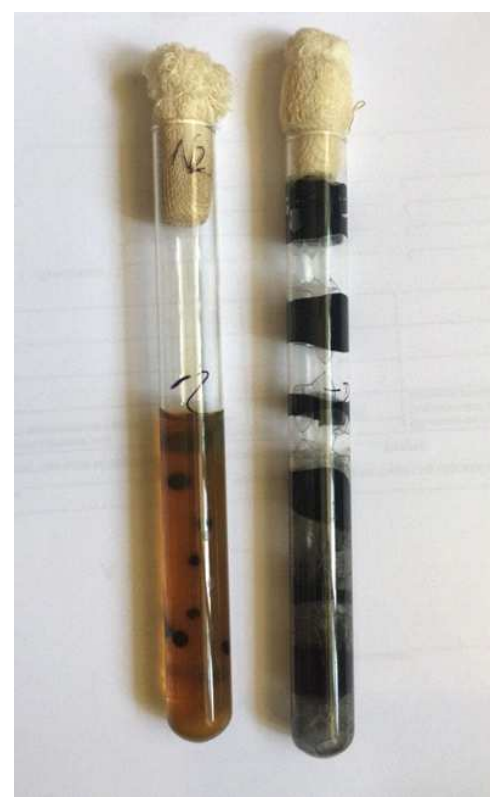

Fig. 3: Cultures of sulfite-reducing clostridia on WilsonBlair medium

In carp, parenchymal organs (kidneys) from 60 specimens were examined and in patients with specimens, an additional seeding was made from skin ulcers. Bacteriological studies consisted the primary pathogen isolation of samples and identification of bacteria. Mediums of nutrient, of selective and differential (Nutrient Agar with $1 \%$ peptone, Nutrient Broth, Hottinger Broth, Endo, Aeromonas Isolation Medium. MacConkey Agar, Vibrio Agar) were used in bacterial inoculation of the clinical samples of tissue and isolation of pure bacterial cultures (Instruction book..., 1998; Weyant et al., 1999;
Buller, 2004; Labinskaya and Volina, 2008). The virulence of aeromonas was determined on the Toluidine Blue DNA Agar (Methodological Instructions, 1997). Clostridium was isolated on the Thioglycollate Agar Reinforced Clostridial Medium, Duncan-Strong, Agar TSN according to State Standard (2010a; 2010b) and Methods of Private Bacteriology (2015). Spores of sulfite-reducing clostridia count of water was determined in the Wilson Blair Agar (Methodological Instructions, 2001). Identification of bacterial cultures by MALDITOF mass spectrometry was performed using an Autoflex speed III Bruker Daltonics (Germany) mass spectrometer with Biotyper software (Kirilyuk, 2014).

Spores of sulfite-reducing clostridia were determined in the normalized volume of water (20 $\mathrm{mL}$ ) (Methodological Instructions, 2001). To quantify the spores in the organs and tissues of fish, $1 \mathrm{~g}$ of the test sample (or its dilution) was used. Samples were heated in a water bath at $(75 \pm 5){ }^{\circ} \mathrm{C}$ for 15 min and filled up with a medium (Labinskaya and Volina, 2008).

The Clostridium abundance was estimated in the Wilson-Bler agar since it is recommended for the use by the Russian standard documents (State Standard, 2010a; 2010b; Labinskaya and Volina, 2008). To determine clostridia, the culture was filled up with cooled to $45^{\circ} \mathrm{C}( \pm 1)$ medium. After the tubes were filled with agar, we immediately placed them in ice water, thus oxygen was removed from the agar and anaerobic conditions for the cultivation of bacteria were created (State Standard, 2010a; 2010b). The culture was incubated at $37^{\circ} \mathrm{C}$ and $44^{\circ} \mathrm{C}$ for $18-24 \mathrm{~h}$, with the following enumeration of the colonies. The results of the analysis were expressed by the number of CFU (colony forming units) in $1 \mathrm{~g}$ or $20 \mathrm{~mL}$ (State Standard, 2010a; 2010b; Labinskaya and Volina, 2008). 


\section{Results}

Contamination by clostridia of commercial fish can be characterized by two parameters: the potential risk of injury and the potential risk of the involvement of these bacteria in pre-existing wound and ulcer processes in fish. Food microbiological safety is determined not only by the quality of finished food products, but also by the quality of raw materials. According to our research, anaerobic bacteremia caused by sulfite-reducing clostridia (Clostridium perfringens, Clostridium sporogenes) was detected in the Black and Azov Seas. In the eastern part of the Taganrog Bay, in the estuary of the Don River, sirman goby specimens were found to be sick with vibriosis and in the shelf zone of the northeastern part of the Black Sea, specimens of the Black Sea flounder with ulcerated skin lesions (unknown etiology) were found. In these diseased fish, organs were contaminated with sulfite-reducing clostridia (Clostridium perfringens, Clostridium sporogenes). C. perfringens is considered a danger of biological origin along the food chain and has a negative impact on health and animals through food contamination and their subsequent consumption. The syrman goby and the Black Sea turbot are objects of intensive fishing; they live in the contaminated bottom layer of the water column; therefore, the sources of their infection with sulfite-reducing clostridia are both water and bottom sediments.

In general, indicators of the dissemination of sulfitereducing clostridia in commercial fish reflect the state of the water bodies their anthropogenic pollution, which is important for economic bodies when deciding whether to implement the necessary measures to improve pools and improve microbiological safety and quality of the species.

In the eastern part of the Taganrog Bay, Vibriosis was diagnosed in the syrman goby Neogobius syrman, Vibrio vulnificus and Vibrio fisheri were causative agents of the disease (2011) (Fig. 4). Spring and summer seasonality were characteristic for the disease.

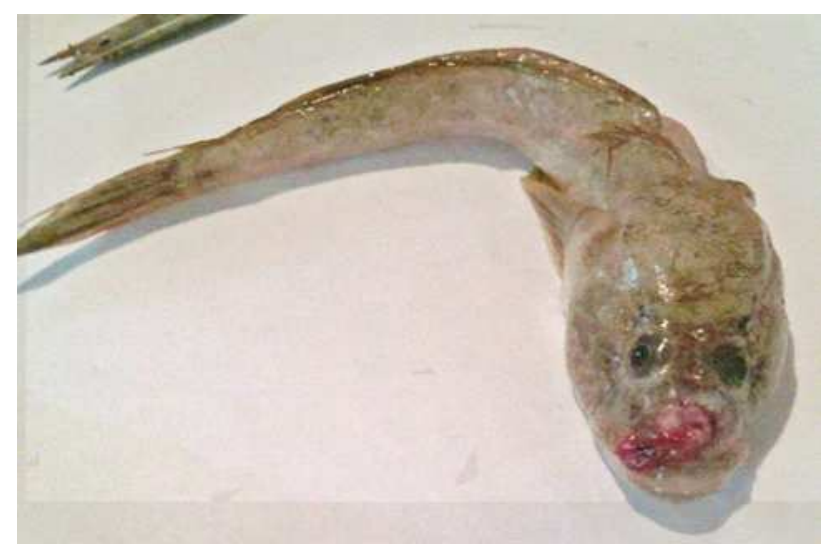

Fig. 4: Ulcerative skin lesions in the syrman goby
Gobies with external pathologies were encountered in June-July at the water temperature of $21-27^{\circ} \mathrm{C}$ in the eastern part of the Taganrog Bay in the areas of the villages of Veselo-Voznesenka and Zolotaya Kosa (Fig. 1). Visual examination of gobies (at least 100 specimens) had shown that $10-13 \%$ of the individuals had clinical signs of the disease. The clinical picture was characterized by redness at the base of the fins and gill covers, moreover, there were hemorrhages on them. Ulcers and red swellings were observed on various parts of the fish skin, sometimes with necrotic phenomena. The autopsy revealed pathological changes in the liver, hemorrhagic inflammation of the kidneys and intestines. In each case, alongside with the causative agents of the disease, $C$. perfringens and $C$. sporogenes were isolated from the contents of skin ulcers, liver and intestines. No clostridia were found in the liver of clinically health fish.

Spores of sulphite-reducing clostridia are of great ecological importance for the coastal zone of the Taganrog Bay. Regardless of the seasons of the year (spring - autumn), spores were a regular component of the water microflora in the areas studied.

It is generally accepted that they indicate old fecal contamination. However, the duration of the survival of these microorganisms in water bodies exceeds that of Salmonella, which demonstrates that this indicator has one of the most important properties of the microorganism indicator. When organic contamination is enhanced, proteolysis and ammonification of Clostridium sporogenes, C. perfringens can be activated, which will eventually lead to the formation of large amounts of hydrogen sulfide and ammonia. Newly entering polluting compounds cause serious changes in the functioning of all aquatic biocenoses, disrupting the biological equilibrium of this ecosystem.

Of importance is the selection of spores from gill tissue (up to $10^{3} \mathrm{CFU} / \mathrm{g}$ ) and intestines $\left(10^{2}-10^{4} \mathrm{CFU} / \mathrm{g}\right)$ of clinically healthy fish. In contamination with clostridia of Azov fish, two maxima were noted - spring and summer-autumn $\left(10^{2}-10^{3} \mathrm{CFU} / \mathrm{g}\right)$. The spring rise in the number of spores coincided with the flood. The summer-autumn maximum (August-September) is due to an increase in water temperature and enrichment of the water body with organic matter. Moreover, this tendency was revealed for the gills of Don fish with the highest values of their numbers $\left(10^{3}-10^{4} \mathrm{CFU} / \mathrm{g}\right)$ and the release of vegetative cells under intensive anthropogenic impact fecal contamination of the Don Delta, which flows into the Taganrog Bay of the Azov Sea (Morozova and Lartseva, 2012; Morozova, 2017). It is noted that in the Taganrog Bay, the average amount of clostridia in water was about 20 units (CFU/ $20 \mathrm{~mL}$ ), with their maximum development in spring and early autumn - 100-200 units (CFU/ $20 \mathrm{~mL}$ ). Given that the contamination of the gills of the goby-sirman with clostridia had no clinical 
consequences, one can only speak about the nature of bacterial contamination of water. After all, to maintain vital activity, fish must pass a large amount of water through the gill apparatus and intestinal tract and the microflora of these organs and the whole organism is formed under the influence of the water microflora (Lartseva and Pivovarov, 2007).

\section{Discussion}

On the issue of detection of genus Clostridium in the gastrointestinal tract of fish there is information on the species C. sporogenes, C. bifermentas and C. botulinum (Pivovarov et al., 1989). At the same time, representatives of the indigenous intestinal flora are a risk factor for the fish with a weakened immune and physiological status and these microorganisms can be a source of endogenous infection. The ability of bacteria to multiply rapidly in the intestines of weakened individuals often leads to bacterial translocation with the development of systemic bacteremia (Simchuk et al., 2005). Studies have shown that in the intestines of the Azov gobies, with signs of bloating and bleeding, a high level of vegetative clostridium cells with pathogenicity factors $\left(10^{6}-10^{8} \mathrm{CFU} / \mathrm{g}\right)$ was noted. Against the background of vibriosis in a syrman goby, this does not exclude a clostridial infection in the intestine whose mucous membrane was damaged by $C$. perfringens.

Studies of the Black Sea turbot Scophthalmus maeoticus maeoticus from the shelf zone of the northeastern Black Sea have revealed cases of regular disease of unknown etiology in this area. The disease was characterized by skin pathologies ulcers and neoplasms (Fig. 5). Detection of ulcerative and neoplastic lesions of the skin in spawning Black Sea turbot has been repeatedly noted by field statistics when using both active (trawls) and passive (fixed nets) fishing gear (Boyko et al., 2013). The literature data indicate a significant effect of fluctuations in environmental conditions on the biological indicators of representatives of this species and the susceptibility of turbot to diseases (Gaevskaya, 2001; Oven, 2001; Girgasov et al., 2007). The occurrence of ulcers and tumors of the skin tends to increase. So, in the spawning period of 2005 , in the catches made by flounder nets, $4-5 \%$ of fish were noted with ulcers and tumor changes in the skin, in 2009 the level was already $10 \%$ (Boyko et al., 2013). It should be underlined that the turbot is a valuable commercial species.

Every year at different stations of the sea there were sampled for microbiological studies at least 10 specimens of turbot, including 3-4 fish with skin pathology (Fig. 2). Microorganisms of the opportunistic pathogenic bacteria Pseudomonas fluorescens, Vibrio parahaemolyticus, Vibrio $s p$. that had infected the blood and liver of the fish were isolated from ulcers and neoplasms (ulcerated and non ulcerated). It is known that $C$. perfringens can enter the body through the wound surface and cause septicemia. The blood and liver of individuals with ulcers and ulcerated tumors were infected with $C$. perfringens, while sick fish with nonulcerated tumors had no sulfite-reducing clostridia.

Since the spores of SRC that contaminated the gills of turbot (10-100 CFU/g) were not found in the water in the fishing areas, the only source of distribution of these microorganisms were bottom sediments. The greater part of pollutants is concentrated in the sediments and is most actively accumulated by bottom species syrman goby or turbot.

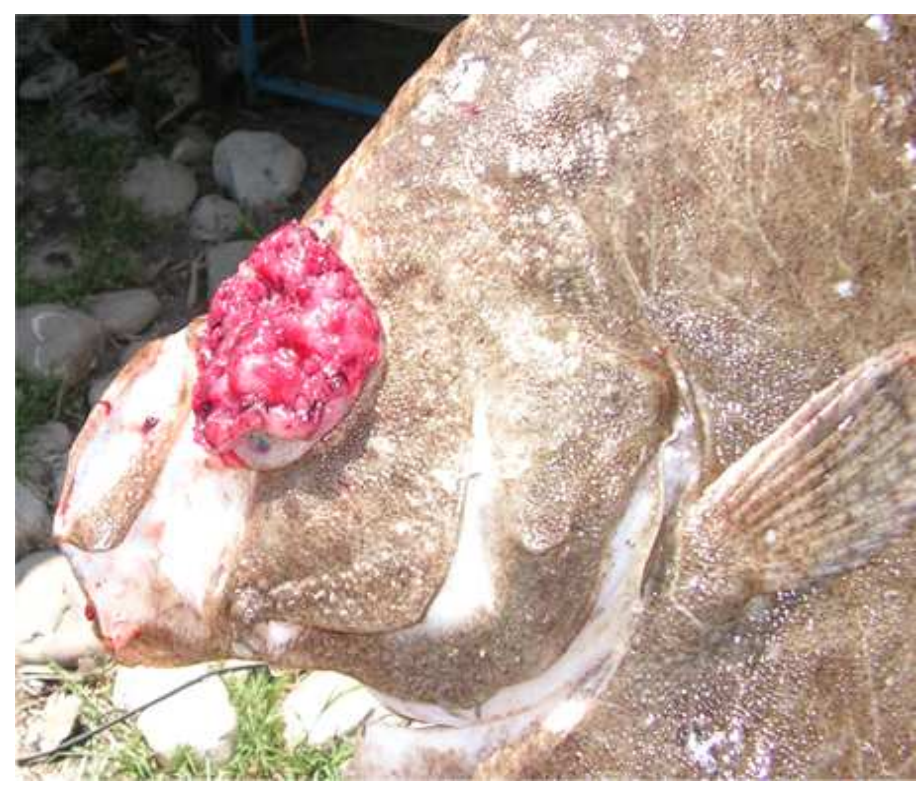

Fig. 5: Turbot with pathology of the skin: papilloma-like neoplasm on the head 


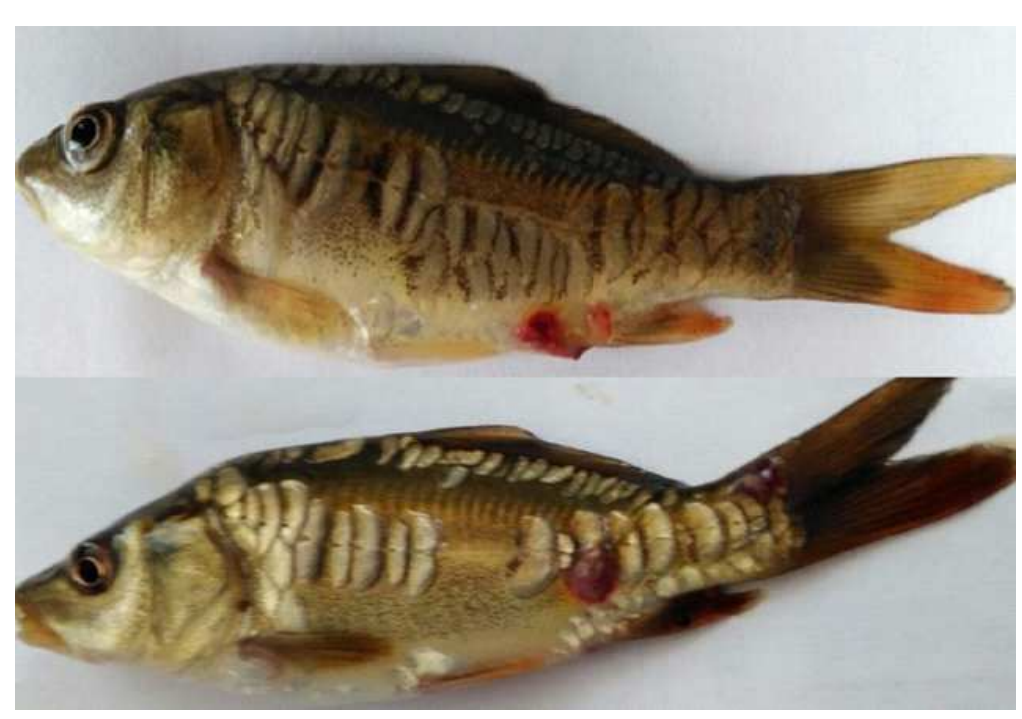

Fig. 6: Carps with manifestations of aeromonosis

It is known that ulcers and tumor skin neoplasms are often noted in fish living in discharge zones of toxic wastes of enterprises, as well as when requirements of industrial rearing are not met (Mikryakov et al., 2000; 2008). Further study is needed of the etiology and diagnosis of the disease of the Black Sea turbot. Much attention is always paid to the microbial factor assessment in the development of pathology. Undoubtedly, the type, number of microorganisms, their pathogenic properties play a significant role in the emergence of complications of the disease and largely determine the nature of its course.

In two farms of the southern region, marketable carps were diagnosed with chronic form of aeromonosis. The etiological agent of the disease were the virulent strains Aeromonas hydrophila. The studies were carried out as part of data collection for the "Unified Industry Database of Ichthyopathological and Epidemiological Surveys of Aquaculture Farms in the Russian Federation".

According to the publications, the south of Russia the Rostov region and the Krasnodar region are among the regions in which aeromonosis is common. The existence of natural foci of the disease in these regions is due to the wild carp population and its ubiquitous habitation in natural water bodies, as well as in ponds of fish farms (Afanas'ev, 1973; 1979). In the Russian Federation aeromonosis is included in the list of quarantine diseases of aquatic animals. Although the spread of the disease is low, the economic damage from carp aeromonosis is very significant (Schelkunov and Yaremenko, 2005; Yaremenko and Machnev, 2000).

For the diagnosis of aeromonosis, samples of kidneys and the contents of ulcers were taken. In parallel, an analysis of clostridia was performed. The prevalence of infection in the samples was 30.8-89.1\%. Our studies have shown that ulcers and kidneys were infected with clostridia in $6.7-10 \%$ of carps with a chronic form of aeromonosis (Fig. 6). Specimens of ulcers and kidneys contained Clostridium difficile and Clostridium novyi pathogenic for humans. Moreover, in parenchymatous organs of clinically healthy carps there were no clostridia. In the ponds water, the content of spores of sulfite-reducing clostridia was 200-300 units. $(\mathrm{CFU} / 20 \mathrm{~mL})$. The presence of pathogenic clostridia in fish and in the habitat indicates the sanitary deprivation of water bodies and the possibility of people being poisoned by this fish and its products. The species associated with diverse pathologies in humans, including the alimentary toxi infections ( $C$. difficile, $C$. novyi, $C$. perfringens); the toxins of the latter affect the nervous and gastrointestinal system respectively (Elika, 2013; OPS, 2016; Cortés-Sánchez, 2018).

\section{Conclusion}

Based on our studies, it can be concluded that clostridia are involved in already existing wound and ulcerative processes in fish. Anaerobic bacteremia caused by sulfite-reducing clostridia (Clostridium perfringens, Clostridium sporogenes) was found in the individuals of syrman goby with a bacterial disease, namely, vibriosis, in the eastern part of the Taganrog Bay where its waters mix with the waters of the Don river; and in turbot with ulcerative lesions of their skin (of unknown etiology) in the shelf zone of the north-eastern Black Sea. The syrman goby and the turbot live at the bottom of the sea that is the most polluted zone, therefore both water and bottom sediments can be the source of fish infection with sulfite-reducing clostridia. These species of fish are objects of fishing, therefore the identification of 
diseased individuals and laboratory control from catch to finished products is an important aspect of the contamination of fish products with spore bacteria. Examination of marketable-size carp with a chronic form of aeromonosis in pond fish farms has revealed that kidneys of $6.7-10 \%$ of sick individuals are infected with pathogenic clostridiums (Clostridium difficile, Clostridium novyi). These species of bacteria are of clinical importance and were found in the parenchymal organs of carp suffering from chronic aeromonas infection on pond fish farms in the southern Russia. Clostridia contamination of fish reflects the state of water bodies and is an indicator of anthropogenic pollution of water bodies, which is important for economic administrative organizations when deciding whether to take necessary measures on waterbodies melioration and microbiological safety and quality of fisheries and aquaculture species.

\section{Acknowledgement}

The work was supported by the Southern Federal University.

\section{Author's Contributions}

Yuriy A. Fedorov: The head of the investigation, designed the research plan and organized the study, coordinated the data-analysis and contributed to the writing of the manuscript.

Marina A. Morozova: Contributed in drafting the manuscript and reviewing it critically for significant intellectual content.

Roman G. Trubnik: Participated in all experiments, collected the field data and contributed to the writing of the manuscript.

\section{Ethics}

This article is original and contains unpublished material. The corresponding author confirms that all other authors have read and approved the manuscript and no ethical issues involved.

\section{References}

Abia, A.L.K., E. Ubomba-Jaswa, M. Du Preez and M.N.B. Momba, 2015. Riverbed sediments in the Apies River, South Africa: Recommending the use of both Clostridium perfringens and Escherichia coli as indicators of faecal pollution. J. Soils Sediments, 15: $2412-2424$.

Afanas'ev, V.I., 1973. New ways to combat the main diseases of fish in the farms of the North Caucasus. Pisciculture and Fishery, pp: 14.
Afanas'ev, V.I., 1979. Aeromonosis of fish and measures to combat it dissertation abstract for the degree of veterinary sciences Ph.D. Moscow, pp: 442.

Andreeva, N.A., 2012. Microbiological processes in the black sea offshore water where sea animals inhabit: A review Scientific Notes of Taurida V.I. Vernadsky National University. Series: Biology, Chemistry, 25: 3-20.

Boyko, N.E., T.V. Strizhakova, O.A. Rudnitskaia, L.P. Ruzhinskaia and M.A. Morozova, 2013. Materials characterization functioning status of the black sea turbot Scophthalmus Maeoticus Maeoticus in spawning period of 2009-2010. Problems of Fisheries. 14: 272-282.

Buck, J.D., L.L. Shepard and S. Spott, 1987. Clostridium perfringens as the Cause of Death of a Captive Atlantic Bottlenosed Dolphin (Tursiops truncatus). J. Wildlife Dis., 23: 488. DOI: 10.7589/0090-355823.3.488

Bukharin, O.V. and V.Yu. Litvin, 1997. Pathogenic bacteria in natural ecosystems. Ekaterinburg: UrO RAN. pp: 277.

Buller, N.B., 2004. Bacteria from fish and other aquatic animals: A practical identification manual. CABI Publishing, CABI International, Walling-ford, U.K. pp: 361.

Cord, D.O., 1982. Dolphins and their diseases. New Zealand Vet. J., 30: 46-49.

Cortés-Sánchez, A.D.J., 2018. Clostridium perfringens in foods and fish. Regulatory Mechanisms Biosystems, 9: 112-117.

Dunn, J.L., 1990. Bacterial and Mycotic Diseases of Cetaceans and Pennipeds. In: Handbook of Marine Mammals Medicine: Helth, Disease and Rehabilitation, Dierauf, L.A., (Edn.,). CRC Press LLC. pp: 73-96.

Elika, 2013. Clostridium. Fundación Vasca para la seguridad agroalimentaria.

El-Shorbagy, M.M., M. Reda Lamyaa and H. Mona, 2012. Prevalence of Clostridium perfringens alpha toxin in processed and unprocessed fish. Int. J. Microbiological Res., 3: 195-199.

Fedorov, Y.A., D.N. Gar'kusha and R.G. Trubnik, 2018. Bacteria of the clostridium genus, methane and hydrogen sulfide in sulfide mud of the taman peninsula reservoirs. OnLine J. Biol. Sci., 18: 315-322.

Gaevskaya, A.V., 2001. Reference book of diseases and parasites of marine and oceanic commercial fish. Sevastopol: ECOSY-Hydrophysics. pp: 262.

Girgasov, V.E., A.N. Khanaichenko and D.E. El'nikov, 2007. Nature and causes of variability in the main indicators of the spawning population of the Black Sea turbot flatfish in the South-Western shelf of Crimea. Modern problems of the Azov-Black Sea region. Mat. III Mezhd. konf. Kerch': IugNIRO. pp: 3-9. 
Greenwood, A.G. and D.C. Taylor, 1978. Clostridial myositis in marine mammals. Vet. Record, 103: 54-55.

Guran, H.S., A. Vural and M.E. Erkan, 2014. The prevalence and molecular typing of Clostridium perfringens in ground beef and sheep meats. J. Consumer Protection Food Safety, 9: 121-128.

Holt, J.G., 1994. Bergey's Manual of Determinative Bacteriology. 1st Edn., Philadelphia: Lippincott Williams \& Wilkins, ISBN-10: 0683006037, pp: 787.

Instruction book, 1998. Instruction book for Disease Control fish. Part 1. M.: Marketing Department of AMB-Agro.

Kanaev, A.I., 1973. Veterinary sanitation in fish farming. M: Spike. pp: 223.

Kirilyuk, A.A., 2014. Application of Mass Spectrometry Methods (HPLC-MS) in a modern clinical laboratory - review of applications, advantages of use, modern approaches and automation capabilities. Clinical Laboratory Diagnostics.

La Sala, L.F., L.M. Redondo, J.M. Díaz Carrasco, A.M. Pereyra and M. Farber et al., 2015. Carriage of Clostridium perfringens by benthic crabs in a sewage-polluted estuary. Marine Pollution Bulletin, 97: 365-372.

Labinskaya, A.S. and E.G. Volina, 2008. Manual on Medical Microbiology. 1st Edn., General and Sanitary Microbiology, Moscow, pp: 1080.

Lartseva, L.V. and Y.P. Pivovarov, 2007. Ecological Epidemiology. Astrakhan. pp: 187.

Methodological Instructions, 1997. 13-4-2/1116 Methodological instructions for determining the pathogenicity of aeromonads on the degree of DNA activity.

Methodological Instructions, 2001. 4.2.1018-01 Sanitary and microbiological analysis of drinking water.

Methods of Private Bacteriology, 2015. [Edited by] Vasiliev D.A., Shcherbakov A.A., Karpunina L.V., Zolotukhin S.N. Study guide. Ulyanovsk. pp: 102.

Mikryakov, D.V., V.R. Mikryakov and L.V. Balabanova, 2008. Character of change of structure leukocytes at stress the induced syndrome of the ulcer diseased of fish (on the example carp Cyprinus carpio). Problems of Fisheries, 9: 936-946.

Mikryakov, V.R., L.V. Balabanova, E.A. Zabotkina, T.B. Lapirova and A.V. Popov et al., 2000. The reaction of the immune system of fish to the effects of certain abiotic environmental factors. VINITI, Moscow.

Moeller, R.B., 1989. Diseases of Marine Mammals. pp: 186.

Morozova, M.A. and L.V. Lartseva, 2012. Microbial communities hydroecosystems of the Lower Don and Taganrog Bay. Natural Sciences.

Morozova, M.A. and Y.A. Fedorov, 2015. Role of sulfite-reducing clostridia in pathology in fish. University News, North-Caucasian Region. Series: Natural Sciences.
Morozova, M.A., 2017. Ecological features of the formation of microbiocenosis of fish Taganrog Bay of the Azov Sea. Ph.D Thesis of Biological Sciences, Rostov-on-Don: Southern Federal University.

OPS, 2016. Organización Panamericana de la Salud. Pan American Health Organization. Peligros biológicos.

Oven, L.S., 2004. Resorption of Vitellogenous Oocites as an indicator of the condition of black sea fish populations and their environment. J. Ichthyology, 44: 124-129.

Pivovarov, Y.P., R.S. Volkova and L.S. Zinevich, 1989. Microflora foods. Results of science and Tehn. VINITI. Series: Microbiology, 22: 69-87.

SanPiN 2.1.4.1074-01, 2001. Drinking water. Hygienic requirements for water quality of centralized drinking water supply systems. Quality Control. Hygienic requirements for ensuring the safety of hot water systems. Approved by the Chief State Sanitary Doctor of the Russian Federation on 26.09.2001.

SanPiN 2.3.2.1078-01, 2001. Sanitary-epidemiological rules and regulations "Hygienic requirements for safety and nutritional value of food". Approved by the Chief State Sanitary Doctor of the Russian Federation on 06.11.2001.

Santos, G. and H. Norma, 2011. Clostridium perfringens: A dynamic foodborne pathogen. Food Bioprocess Technology, 4: 624-630.

Schelkunov, I.S. and N.A. Yaremenko, 2005. Epizootological monitoring is a necessary and real condition for the sustainable development of aquaculture and ensuring the well-being of water bodies in Russia. Proceedings of the Epizootological monitoring in aquaculture: State and prospects. Extended materials of the All-Russian scientificpractical conference-seminar, Sep. 13-14, Moscow: Russian Agricultural Academy, pp: 145-148.

Sheyin, A.N. and K.J. Solomon, 2017. Endo microbial fauna of Tilapia spp. (Oreochromis niloticus) found in a Flowing Canal at Eden Garden and Park Utako, Abuja. J. Fisheries Livestock Production, 5: 214.

Simchuk, G.V., V.L. Zubachenko and S.O. Omel'chenko, 2005. Evaluation of microbial contamination of sea water and mass fish species of the coastal part of the Black and Azov Seas. Odesa National University Herald, 10: 201-207.

State Standard, 2010a. 29185-91 Food products. Methods for detecting and determining the number of sulfite-reducing clostridia.

State Standard, 2010b. 10444.9-88 Food products. Method for determination of Clostridium perfringens.

Trubnik, R.G., Y.A. Fedorov and L.A. Nedoseka, 2017. Recovered gases and bacteria from the Clostridium genus as ecological condition indicators of bottom sediments of the Eastern Donbass small rivers. OnLine J. Biological Sci., 17: 201-210. 
Tymchuk, S.N., V.E. Larin and D.M. Sokolov, 2013. Most significant sanitary microbiological parameters of drinking water quality assessment. Water Supply Sanitary Technique.

Weyant, R., U. Moss, R. Uiver, D. Hollis and D. Dzhordan et al., 1999. Determinant of nontrivial pathogenic gram-negative: Moscow. pp: 792.
Yaremenko, N.A. and A.N. Machnev, 2000. Epizootic situation on infectious diseases of fish in the Russian Federation. Problems of protecting the health of fish in aquaculture. Proceedings of the Materials of the Scientific-Practical Conference. Nov. 21-22, Moscow: Russian Agricultural Academy, Moscow, pp: 10-13. 